\title{
Role of TRP channels in dendritic integration and subthreshold membrane potential plateaus
}

\author{
Marcus E Petersson*, Erik A Fransén \\ From Twentieth Annual Computational Neuroscience Meeting: CNS*2011 \\ Stockholm, Sweden. 23-28 July 2011
}

Cortical as well as subcortical neurons display plateau properties [1]. The plateaus may be voltage and/or calcium gated and depend on $\mathrm{Na}, \mathrm{Ca}$ or mixed cation (TRP) currents. Depending on the nature of the synaptic input, neurons may respond by entering one of several multiple stable states, in the form of either subthreshold or persistent firing. We have studied the activation of a TRP current, in which synaptic excitatory input activates metabotropic glutamate receptors in turn leading to a TRP-mediated slow EPSP, both experimentally [2] and computationally [3]. In the computational work we have studied the contribution of the TRP current on dendritic integration of input of low $(1-10 \mathrm{~Hz})$ frequency.

The model is based on a CA1 pyramidal cell model [4] developed to study dendritic processing. The spatial compartmentalization had been obtained from a

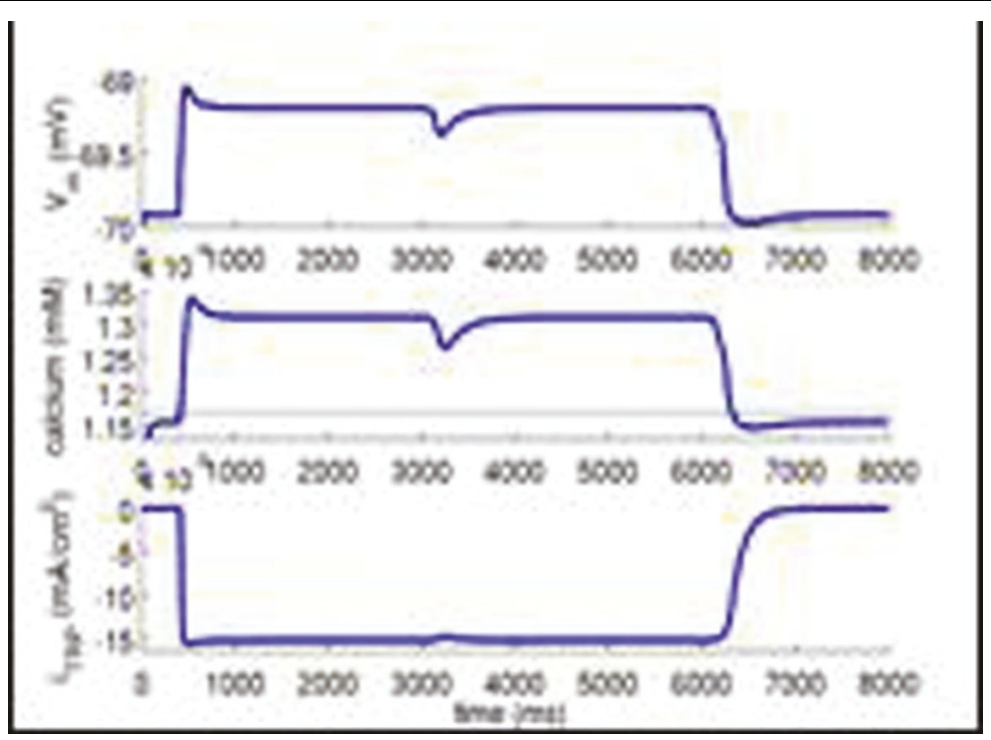

Figure 1 The membrane voltage $\left(V_{m}\right)$ is resting close to $-70 \mathrm{mV}$. At the arrival of an excitatory synaptic stimulus, $V_{m}$ enters a more depolarized, subthreshold plateau, which is stable to weak inhibitory input $(t=3000 \mathrm{~ms})$. $V_{\mathrm{m}}$ returns to its resting state only if strong inhibitory input is applied $\left(t=6000 \mathrm{~ms}\right.$ ). This intrinsic upstate is due to the dynamical balance between the calcium concentration, $V_{\mathrm{m}}$ and calcium, TRP and outward currents.

\footnotetext{
* Correspondence: mepeter@kth.se

Dept. of Computational biology, School of Computer Science and Communication; Stockholm Brain Institute, Royal Institute of Technology,

AlbaNova University Center, Stockholm, SE-106 91, Sweden

Full list of author information is available at the end of the article
}

(c) 2011 Petersson and Fransén; licensee BioMed Central Ltd. This is an open access article distributed under the terms of the Creative 
digitized neuron and contains 183 compartments. It includes ion channels described by a Hodgkin-Huxley formalism and has the following channels: $\mathrm{Na}, \mathrm{Na}_{\mathrm{P}}, \mathrm{Ca}_{\mathrm{R}}$, $\mathrm{Ca}_{\mathrm{T}}, \mathrm{Ca}_{\mathrm{L}}, \mathrm{K}_{\mathrm{dr}}, \mathrm{K}_{\mathrm{A}}, \mathrm{K}_{\mathrm{M}}, \mathrm{K}_{(\mathrm{Ca}) \mathrm{BK}}, \mathrm{K}_{(\mathrm{Ca}) \text { slow }}, \mathrm{K}_{\text {leak }}$, h. To this model we added models for a metabotropic glutamate receptor as well as a TRP channel, the latter being adapted from a CAN channel model.

Continuing our computational work, we have recently studied how the dendritic integration properties depend on the time constant of the calcium activating the TRPcurrent. In the model calcium comes from L-type Cav1.3 channels with a low threshold but there may also be contributions from T-type channels. We find that the effective integration time constant, the decay time constant of the neuronal membrane, increases when the amplitude of the calcium concentration increases. Moreover, recent experimental work [5] has shown that the decay time constant of calcium increases as a result of increased calcium concentration. This prompted us to study effects of adding a slower decay time constant in addition to the one present in the model used so far. Intriguingly, we find that a stable subthreshold plateau appears when a slower $(200 \mathrm{~ms})$ calcium decay time constant is present but not when only the original faster $(30 \mathrm{~ms})$ is present. This plateau of the resting potential is stable for weaker synaptic excitatory or inhibitory input, but stronger input can switch the membrane between the two levels, see figure 1 . We find that the subthreshold plateau is essentially local to individual dendritic branches, and that the cell enters a persistent spiking [1] mode when several branches enters plateau mode. This bistability in membrane potential due to intrinsic conductances may be compared to the network driven changes of subthreshold membrane potential during cortical up and down states, suggested to switch the neuron between different modes of integration/operation.

Published: 18 July 2011

\section{References}

1. Fransén E, Tahvildari B, Egorov AV, Hasselmo ME, Alonso AA: Mechanism of graded persistent cellular activity of entorhinal cortex layer $v$ neurons. Neuron 2006, 49(5):735-46.

2. Yoshida $M$, Fransén E, Hasselmo ME: mGluR-dependent persistent firing in entorhinal cortex layer III neurons. Eur J Neurosci 2008, 28(6):1116-1126.

3. Petersson ME, Fransén E: TRPC channels activated by group I mGluR in entorhinal pyramidal neurons support integration of low frequency $(<10$ $\mathrm{Hz}$ ) synaptic inputs. BMC Neuroscience 2009, 10:P26.

4. Poirazi P, Brannon T, Mel BW: Arithmetic of subthreshold synaptic summation in a model CA1 pyramidal cell. Neuron 2003, 37(6):977-987.

5. Scheuss V, Yasuda R, Sobczyk A, Svoboda K: Nonlinear [Ca2+] signaling in dendrites and spines caused by activity-dependent depression of Ca2+ extrusion. J Neurosci 2006, 26(31):8183-94.
doi:10.1186/1471-2202-12-S1-P110

Cite this article as: Petersson and Fransén: Role of TRP channels in dendritic integration and subthreshold membrane potential plateaus. BMC Neuroscience 2011 12(Suppl 1):P110.

\section{Submit your next manuscript to BioMed Central and take full advantage of:}

- Convenient online submission

- Thorough peer review

- No space constraints or color figure charges

- Immediate publication on acceptance

- Inclusion in PubMed, CAS, Scopus and Google Scholar

- Research which is freely available for redistribution

Submit your manuscript at www.biomedcentral.com/submit
C Biomed Central 